\title{
The effect of the exchange rate system on the economic growth of Bosnia and Herzegovina
}

\section{Утицај система девизног курса на економски раст Босне и Херцеговине}

\author{
Dražen Marjanac * \\ Ministry of Trade and Tourism, Government of Republika Srpska, Banja Luka, Bosnia and Herzegovina, \\ d.marjanac@gmail.com
}

\begin{abstract}
The subject of the research refers to the analysis of the influence of the exchange rate system in Bosnia and Herzegovina $(\mathrm{BiH})$ on the macroeconomic indicators of economic growth. The goal of the research is to provide a theoretical and analytical overview of the mechanism of functioning and influence of the exchange rate system on inclusive economic growth in the long run. The research was conducted by applying the analysis of relevant literature, method of deduction and econometric calculations of the influence of the exchange rate system on macroeconomic indicators, that is, on gross domestic product, employment and trade balance. The research will offer an answer to the research question: Does the exchange rate system have an influence on the economic growth of Bosnia and Herzegovina in the long run? The results of the research will show the existence of the relation and influence of the exchange rate system on targeted macroeconomic parameters. Conclusions of the research relate to the confirmation of the basic hypothesis that the exchange rate of the convertible mark has bounded affect the growth of gross domestic product, employment and trade balance of Bosnia and Herzegovina in the long run. The contribution of the research is to present to the scientific and professional public the results of the analysis of the influence of the exchange rate system on economic growth, as well as possible alternatives and changes in the system that will enable faster and more stable economic growth in the long run.
\end{abstract}

Keywords: exchange rate system, gross domestic product, employment, trade balance, economic growth. JEL classification: F31, F43

Сажетак: Предмет истраживања односи се на анализу утицаја система девизног курса у Босни и Херцеговини на макроекономске показатеље економског раста. Циљ истраживања је да се омогући теоријски и аналитички преглед механизма функционисања и утицаја система девизног курса на инклузиван и одржив економски раст у дугом року. Истраживање је спроведено применом анализе релевантне литературе, методе дедукције и економетријским израчунима утицаја система девизног курса на макроекономске показатеље, односно, на бруто домаћи производ, запосленост и трговински биланс. Истраживање ће понудити и одговор на истраживачко питање: Да ли систем девизног курса има утицај на економски раст Босне и Херцеговине у дугом року? Резултати истраживања показаће постојање релације и утицаја система девизног курса на таргетиране макроекономске параметре. Закључци истраживања односе се на потврђивање основне хипотезе да девизни курс конвертибилне марке има утицај на раст бруто домаћег производа, запосленост и трговински биланс Босне и Херцеговине у дугом року. Допринос истраживања је да се научној и стручној јавности представе резултати анализе утицаја система девизног курса на економски раст као и могуће алтернативе и промене система који ће омогућити бржи и стабилнији

Corresponding author 
економски раст у дугом року.

Кључне речи: систем девизног курса, бруто домаћи производ, запосленост, трговинси биланс, економски раст

JEЛ класификација: F31, F43

\section{Introduction}

The choice of the exchange rate system is one of the most complex and most discussed macroeconomic issues. Determining the appropriate exchange rate system for a country is a prerequisite for the success of economic policy measures in terms of increasing production, employment, demand, exports and GDP. Therefore, the choice of the exchange rate, in accordance with the comprehensive characteristics of one country, is an extremely important issue that has long-term implications for economic growth.

The currency board system represents an institution whose role is the money issue that is convertible into foreign currency at a fixed exchange rate determined by law. Its primary role refers to maintaining the stability of the economic system and prices.

After the breakup of the SFRY, the economy of Bosnia and Herzegovina was at an extremely low level of productivity and technological development, and order in the monetary system had to be introduced in order to create conditions for economic growth. Therefore, there was a need for the introduction of a currency board that proved to be effective in the short and medium term for a large number of countries that have found themselves in financial and structural economic crises.

The system in Bosnia and Herzegovina has remained functional until today without any major pressures for its abolition. The currency board system enabled the functioning of a stable economic system without major turbulence and inflationary shocks, but with limited results in terms of economic growth.

The basic problem of the research is sublimated in the question whether the exchange rate system has an influence on the economic growth of Bosnia and Herzegovina in the long run. Using the analytical procedures and the deduction method, the basic hypothesis of the research will be proved: The exchange rate of the convertible mark has affect the growth of gross domestic product, employment and trade balance of Bosnia and Herzegovina in the long run.

The first part of the research refers to the processing of literary materials with relevant data and opinions of the author from the previous research related to the subject of the research. The second part describes the basic characteristics of the currency board system and the experience of the countries that applied it. The third part of the paper is a research chapter where, on the basis of the relevant data available at the time of the research, the basic hypothesis of the paper will be proved using econometric methods. The fourth part contains results of analysis and opinions and estimates related to the 
choice of the second, optimal exchange rate system. The fifth part refers to the discussion and conclusion regarding the obtained results of the research.

\section{An overview of previous research}

The price at which one currency is exchanged for another is called the exchange rate. Unlike the nominal exchange rate, the real exchange rate represents the rate at which one person can exchange goods and services of one country for the goods and services of another country (Mankiw \& Taylor, 2006, p. 648). The central issue among many macroeconomists, since abandoning the Bretton Woods system of gold-dollar parity, is the choice of the appropriate exchange rate system. There are three basic exchange rate systems. Fixed exchange rate is the rate defined by the decision of the central bank and does not depend on variations in the foreign exchange market. The fluctuating exchange rate is formed on the foreign exchange market, based on the supply and demand for foreign currency. Allowing the free formation of the exchange rate has never existed, although it has been mentioned in the literature, because the exchange rate is an overly significant instrument to be left to free formation in foreign exchange markets and speculative mechanisms. A managed fluctuating exchange rate is a fluctuating exchange rate with a defined fluctuation range. The task of the central bank, as a monetary authority, is to select the most compatible exchange rate system, in accordance with the economic and other characteristics of the country.

The initial research in the field of the exchange rate system relates to the work of many authors (Mundell, 1961; McKinnon, 1963; Kenen, 1969), who focused on the choice of the exchange rate system, the ability of countries to tackle demand shocks and the benefits of monetary policies. Based on research by Barro and Gordon (1983) into the credibility of monetary policy, literature in the $1980 \mathrm{~s}$, according to von Hagen and Zhou (2005), developed the idea that the fixing of the exchange rate significantly helps to create the credibility of inflation policy.

Another general problem in macroeconomic theory, according to Hefeker (1997), is the inability to provide a theoretical or empirical assessment of the cost and usefulness of a particular exchange rate. That is, the problem directly extends to measuring the profit from a stable exchange rate, in terms of the sensitivity of the variability and the inability to isolate the effects of the uncertainty of the exchange rate.

Rusydi and Islam (2005), based on empirical studies, argued that increasing of the exchange rate variability led to a reduction in the volume of international trade. Their hypothesis is based on the assumption that, in the case of international transactions, goods and services are delivered in a time gap between the moment of contracting and delivery, in which the variation of exchange rates significantly affects the volume of trade. 
Krugman (1991), Krugman and Miller (1992) and Svensson (1992) agree with the above assertions, but with the modification of the aforementioned theory. Their recommendation for countries when choosing a foreign exchange rate is to opt for the area between fixed and fluctuating exchange rates, known as the target zone system. The main advantage of this system is the limitation of fluctuations in the exchange rate, but that it still allows its minimal oscillations in credible target zones.

On the other hand, Husain, Mody and Rogoff (2005) believe that for countries, and especially for the poor and developing countries that have little access to the international capital market, it is better to fix the value of their currencies. But, when countries become richer and financially more developed, they benefit from shifting more towards fluctuating exchange rate systems.

The key issue of choosing a foreign exchange rate is a trade-off between price stability and economic growth/external competitiveness. Many authors, (Sachs, 1996, Halpern \& Wyplosz, 1997; Szapáry \& Jakab 1998), dealt with a "conflict" between price stability and an increase in external competitiveness in a short period of time. Halpern and Wyplosz (1997) emphasized the inevitability, for developing countries, of the appreciation of the exchange rate due to the application of a stable price policy. Sachs (1996) strongly believed that the fixed exchange rate was the basis for the commitment of central banks to price stability. After levelling off a high inflation rate, in order to eliminate structural weaknesses and external shocks, the central bank's commitment should go towards the system of fluctuating exchange rates.

After measuring the effects of the exchange rate system on inflation and economic growth, one of the fundamental decisions, according to De Grauwe and Schnabl (2008), is to determine the appropriate exchange rate system that provides economic stability. The choice of the exchange rate should go towards increasing production, employment, income, demand, exports, and thus GDP, while ensuring the inflation rate that does not undermine real economic growth.

The choice of the exchange rate system is a complex macroeconomic issue and is the subject of numerous debates. There is no identical or similar formula for the success of the application of a particular system, but the corresponding economic laws must be taken into account when choosing a foreign exchange rate system. Thus, it is more efficient for the poor and transition countries to adopt a fixed exchange rate system in the short and somewhat medium term in order to suppress inflation and create conditions for economic growth. After reaching the targeted goals, the tendency should be to leave the system of fixed exchange rates allowing the fluctuation of exchange rates, with the possibility of a fluctuation range, in accordance with the goals of monetary policy. 


\section{Basic characteristics of the currency board system}

According to Burda and Wyplosz (2004), Krugman and Obstfeld (2009), Baldwin and Wyplosz (2010), Blanchard (2009), Kovačević (2016), the currency board system represents the institution that issues banknotes and coins, completely convertible into foreign currency that in this case has the character of the reserve currency, and it is fixed at a fixed rate, which is as a rule defined by law. So, its role is, primarily, to maintain a stable economic system of a country, price stability, i.e. low inflation rate.

The currency board proved to be an effective system in lowering the high rate of inflation in the short term, but also the limiting factor in financing the budget deficit by the monetary authorities. However, the inability to finance budget deficits has also its good sides, in terms of controlling the issuing of money, especially without coverage that could be used for the budget deficit, which may have negative implications on the amount of money in circulation and economic development.

The most common reasons why currency boards are introduced relate to problems of macroeconomic equilibrium, transitional reforms, the opening of economies and war conflicts. The system is characterized by simplicity, transparency and precisely defined rules. The currency board, according to Kozarić (2007), is characterized by several important elements, which are:

- automation system,

- credibility,

- fixed exchange rate and convertibility,

- total coverage of the domestic currency with a reserve currency,

- political independence and trust,

- legal regulation.

The currency board system seeks to ensure the convertibility of the domestic currency, macroeconomic discipline, price and monetary stability, stimulation of foreign trade and foreign direct investments, development of financial markets and the banking sector. The method of creating a money supply in the currency board system is similar to the gold standard system. This means that countries can issue as much national money as they have coverage in the currency they are tied to.

However, one of the most important reasons for its introduction in transition countries is the high degree of susceptibility of central monetary authorities to political influences in terms of financing budget deficits and the purchase of social peace which lead to a high inflation rate and, in combination with a low rate of economic activity, have long-term consequences on economic growth and development. 
The success of the currency board system depends on other aspects of economic policy, such as the level of initial reserves, flexibility of fiscal policy instruments, interest rate variations, and labor market flexibility. In addition to the emphasized advantages, the currency board also has its disadvantages that negatively affect economic activity. The biggest disadvantages are:

- limitations and the possibility of banning the granting of loans, which may have negative implications for the banking sector;

- disabling the implementation of autonomous and active monetary policy;

- limited protection against speculations on the market.

Criticism of the system mainly relates to the automatism of the system and the lack of freedom of monetary authorities. The Central Bank does not have the ability to implement discretionary monetary policy, so the currency board actually serves as a stabilizer of the foreign exchange rate and prices. Adapting the economy to negative developments in the markets refers to the adapting of economic activity, money supply, level of domestic prices, employment and salaries. What is particularly emphasized in criticisms is the inefficiency of holding reserves, in the sense of disabling the use of available resources that would be available, primarily to the economy.

\section{Influence of the exchange rate system on the economic growth of Bosnia and Herzegovina}

In order to understand the reasons for the introduction of the currency board in $\mathrm{BiH}$, it is necessary to look at the economic and, first of all, political aspects, which resulted in its introduction. After the breakup of the SFRY, Bosnia and Herzegovina dinar (BHD) was introduced in $\mathrm{BiH}$, as a means of payment in the payment system of $\mathrm{BiH}$. The conversion of the Yugoslav dinar (JUD) to BHD was made at the rate of 1 BHD for 10 JUD. Deposit money was replaced by conversion at a given exchange rate through the Department of Public Auditing. In that period, three currencies were circulating in the territory of $\mathrm{BiH}$. Since there were problems in securing the BHD and its pegging to neighboring currencies, the German mark (DEM) began to be used as a means of payment since the second half of 1994. At the exchange rate, BHD was pegged to DEM, where 350 BHD should be paid for $1 \mathrm{DEM}$. Under conditions of economic collapse and hyperinflation, there was a need for additional cash, which was not possible to be printed in such amount, so DEM was increasingly used as a means of payment.

After signing the Dayton Agreement, the issues of constituting and functioning of central monetary authorities in $\mathrm{BiH}$ were defined. The currency board in $\mathrm{BiH}$ and other issues related to the Central Bank of $\mathrm{BiH}(\mathrm{CBBH})$ were defined in Annex IV of the Dayton Agreement. Article VII of the Constitution defines the competence of BiH institutions in terms of the implementation of monetary policy. The currency board, as a 
model of monetary policy management, has been applied since the founding of the CBBH in 1997.

The currency used in $\mathrm{BiH}$, the Convertible Mark (BAM), was fixedly pegged to the then DEM, and after the introduction of the single European currency, to the Euro (EUR), at the defined exchange rate of 1 BAM for 0.51 EUR. During the years of implementation, the currency board system has to a greater extent successfully achieved the following goals:

- monetary stability,

- strengthening financial stability and discipline,

- low inflation rate,

- $\quad$ attracting foreign investments,

- continuous growth of foreign reserves,

- development of the financial market,

- $\quad$ servicing of the external debt of the country.

The currency board in the conditions of $\mathrm{BiH}$ is defined as a rule that anyone who wants to have BAM must buy that money for a foreign convertible currency. When domestic money is bought for some foreign currency, these transactions are executed at the market exchange rate. This means that the monetary liabilities of the $\mathrm{CBBH}$ cannot be higher than the CBBH's foreign exchange assets. Taking into account the balance of payments of $\mathrm{BiH}$, that is, foreign trade, the $\mathrm{CBBH}$ can issue the amount of domestic money that is proportional to the export. This means that if the $\mathrm{BiH}$ economy exports products and services worth $100 \mathrm{EUR}$, the $\mathrm{CBBH}$ can issue 195,583 BAM. The aforementioned money issuing mechanism, in the conditions in which $\mathrm{BiH}$ was and still is, represents the most efficient mechanism in terms of controlling the money supply and the inflation rate.

\subsection{Influence of the exchange rate system on the gross do- mestic product of BiH}

The subject of the research analysis refers to the determination of the relation and the strength of a relationship between the exchange rate system and the targeted macroeconomic parameters. Foreign exchange rate of $\mathrm{BiH}$, i.e. the effective exchange rate is calculated in accordance with the methodology of the European Central Bank. The calculation of nominal effective exchange rate (NEER) and real effective exchange rate (REER) is performed according to the above methodology. 
The nominal effective exchange rate represents the weighted average of the bilateral exchange rates of the convertible mark in relation to the currencies of the most important foreign trade partners. The method of calculating the nominal effective exchange rate, according to the Central Bank of $\mathrm{BiH}(2018)$ is:

$$
N E E R^{t}=\prod_{i=1}^{N}\left(e_{K M, i}^{t}\right)^{w_{i}}
$$

where:

- $\mathrm{N}$ - the number of countries in the reference group of trading partners,

- $\quad e_{K M, i}^{t}$ - index of the average exchange rate of the KM currency vis-à-vis the partner country $i$ in the period $t$ (expressed in the number of units of the domestic currency in relation to the foreign currency),

- $w_{i}$ - weight assigned to the currency of the trading partner $i$.

Table 1: Nominal and real effective exchange rate of $\mathrm{BiH}$

\begin{tabular}{|c|c|c|}
\hline & NEER & REER \\
\hline 2006 & 99,28 & 98,25 \\
\hline 2007 & 98,70 & 97,07 \\
\hline 2008 & 98,84 & 99,07 \\
\hline 2009 & 101,95 & 99,80 \\
\hline 2010 & 101,41 & 99,01 \\
\hline 2011 & 102,05 & 99,54 \\
\hline 2012 & 102,65 & 98,75 \\
\hline 2013 & 103,55 & 97,02 \\
\hline 2014 & 104,99 & 96,32 \\
\hline 2015 & 103,92 & 93,71 \\
\hline 2016 & 105,22 & 93,15 \\
\hline 2017 & 106,04 & 93,05 \\
\hline
\end{tabular}

Source: Central Bank of Bosnia and Herzegovina

According to the given methodology, the weightings for the calculation of the effective KM exchange rates are based on the structure of imports and exports of the goods of the processing industry. The usual, i.e. more precise methodology used to calculate the trade weight is the share of imports and exports related to that country in relation to imports and exports to all countries that enter the calculation. However, this methodology is not the subject of calculation because it is not used by the CBBH. The weights, according to the CBBH methodology, reflect direct import competition, direct export competition and export competition in third markets. The selection of countries entering the basket is determined on the basis of the participation of each partner country 
in the total external trade of the processing industry of BiH. According to the above criterion, the group of countries for establishing the effective exchange rate index of the KM consists of 21 most important trading partners. These countries make up about $90 \%$ of total external trade in BiH's processing products.

The real effective exchange rate is defined as the nominal effective exchange rate that is deflated by the relative prices, i.e. by the Consumer Price Index (CPI) and the Producer Price Index (PPI), in the domestic economy and trading partners' economies denominated in the single currency. The method of calculating the real effective exchange rate, according to the Central Bank of $\mathrm{BiH}$ (2018), is:

$$
R E E R^{t}=\prod_{i=1}^{N}\left(\frac{d_{K M}^{t} e_{i, K M}^{t}}{d_{i}^{t}}\right)^{w_{i}}
$$

where:

- $\mathrm{N}$ - the number of countries in the reference group of trading partners,

- $e_{K M, i^{-}}^{t}$ index of the average exchange rate of the KM currency vis-à-vis the partner country $i$ in the period $t$,

- $\quad t, d_{K M}^{t}$ and $d_{i}^{t}$ represents deflators vis-à-vis the partner country $i$

- $\quad w_{i}$ - represents the weight assigned to the trading partner's currency $i$.

Calculating effect and influence the effective exchange rate on the targeted macroeconomic indicators of $\mathrm{BiH}$ is based on linear regression model. The regression model will analyze the relation and the influence of the independent variable (nominal effective exchange rate) on dependent variables (nominal gross domestic product). The regression model for calculating the influence of an independent variable on a dependent variable is presented in the following way:

$$
Y=A_{0}+A_{1} X_{1}+\varepsilon
$$

where:

- $\quad Y=$ dependent variable ( nominal GDP)

- $\quad X_{j}=$ independent variable (NEER)

- $\quad A_{0}=$ Constant

- $A_{1}=$ unknown parameter alongside the independent variable 
- $\quad \varepsilon=$ an error that reflects all influences on the dependent variable (GDP) that do not stem from an independent variable

The targeted macroeconomic indicators of $\mathrm{BiH}$, based on the available relevant statistical indicators, are presented in Table 2. The author's calculations also included the rate of real GDP growth and the inflation rate in order to compare the obtained results with the stated macroeconomic indicators and to provide more precise results of the overall influence of the exchange rate on the movement of the given macroeconomic indicators.

Table 2: BiH macroeconomic indicators

\begin{tabular}{|c|c|c|c|c|c|c|}
\hline & $\begin{array}{c}\text { GDP } \\
\text { (nominal) }\end{array}$ & $\begin{array}{c}\text { Current } \\
\text { account }\end{array}$ & $\begin{array}{c}\text { Unemployment } \\
\text { rate }\end{array}$ & $\begin{array}{c}\text { Rate of real } \\
\text { GDP } \\
\text { growth }\end{array}$ & $\begin{array}{c}\text { Inflation } \\
\text { rate }\end{array}$ & CPI Index \\
\hline 2006 & 20.052 & -2.041 & 31.1 & 5.3 & 6.1 & 106.1 \\
\hline 2007 & 22.541 & -2.236 & 28.9 & 5.7 & 1.5 & 101.5 \\
\hline 2008 & 25.511 & -4.532 & 23.3 & 5.4 & 7.4 & 107.4 \\
\hline 2009 & 24.792 & -1.945 & 24.0 & -3.0 & -0.4 & 99.6 \\
\hline 2010 & 25.357 & -1.787 & 27.2 & 0.9 & 2.1 & 102.1 \\
\hline 2011 & 26.223 & -3.060 & 27.6 & 1.0 & 3.7 & 103.7 \\
\hline 2012 & 26.215 & -2.563 & 28.0 & -0.8 & 2.1 & 102.1 \\
\hline 2013 & 26.771 & -1.666 & 27.4 & 2.4 & -0.1 & 99.9 \\
\hline 2014 & 27.351 & -2.362 & 27.5 & 1.2 & -0.9 & 99.1 \\
\hline 2015 & 28.577 & -1.521 & 27.6 & 3.1 & -1.0 & 99.0 \\
\hline 2016 & 29.891 & -1.511 & 25.0 & 3.1 & -1.1 & 98.9 \\
\hline 2017 & 31.250 & -1.499 & 25.5 & 2.7 & 1.2 & 101.2 \\
\hline
\end{tabular}

Source: Central Bank of Bosnia and Herzegovina

By econometric calculation, based on the determined model, the values of the correlation coefficient and the coefficient of determination were obtained. The value of the correlation coefficient is 0.871 . The stated value of the correlation coefficient, of $87.1 \%$, shows a high correlation between the variations of the independent and the dependent variable, i.e. NEER and GDP. In order to obtain a more reliable and more accurate indicator of the influence of variations of dependent on an independent variable, the determination coefficient is calculated. 
Chart 1: Scatter plot NEER/GDP

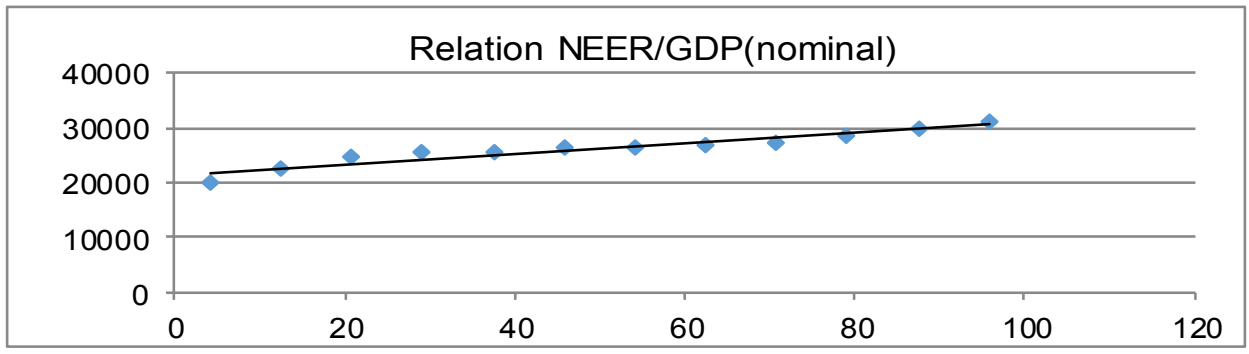

Source: Author's calculation

The value of the determination coefficient of 0.759 shows a high degree of influence of the variation of the independent variable on the dependent variable. This means that $75.9 \%$ of the variability of the dependent variable can be explained by the influence of an independent variable. The remaining $24.1 \%$ of the variation of the dependent variable is influenced by other macroeconomic and other factors. The scatter plot shown in Chart 1 shows a positive linear relationship between the dependent and independent variables, i.e. NEER and GDP.

\subsection{Influence of the exchange rate system on employment}

The same model will analyze the degree of a relationship and the influence of an independent variable (nominal effective exchange rate) on the second targeted macroeconomic variable, i.e. the dependent variable (unemployment rate). The regression model for calculating the influence of an independent variable on a dependent variable is presented in the following way:

$$
Y=A_{0}+A_{1} X_{1}+\mathcal{E}
$$

where:

- $\quad Y=$ dependent variable (unemployment rate)

- $\quad X_{j}=$ independent variable (NEER)

- $A_{0}=$ Constant

- $A_{1}=$ unknown parameter alongside the independent variable 
- $\varepsilon=$ an error that reflects all influences on the dependent variable (unemployment rate) that do not stem from an independent variable

Chart 2: Scatter plot NEER/unemployment rate

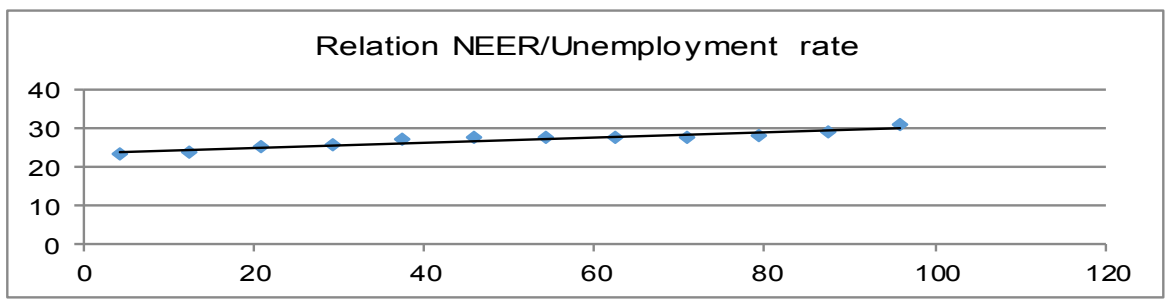

Source: Author's calculation

Calculation of the coefficient of correlation and determination determines the strength of a relationship and the influence of the independent on the dependent variable. The value of the correlation coefficient of 0.233 shows the existence of a relationship, but not the strong relationship between the nominal effective exchange rate and the unemployment rate. The value of the determination coefficient of 0.544 was obtained by quadrating the correlation coefficient.

The value of the coefficient of determination shows that $54.4 \%$ of the variability of the dependent variable can be explained by the influence of an independent variable. This means that the nominal effective exchange rate has an influence, but not a high percentage, on the movement of the unemployment rate. The scatter plot graphically depicts the relationship between an independent and dependent variable.

\subsection{Influence of the exchange rate system on the trade bal- ance}

The econometric model used in the analysis of the previous macroeconomic indicators will analyze the degree of a relationship and the influence of an independent variable (nominal effective exchange rate) on the dependent variable (trade balance). The regression model for calculating the influence of an independent variable on a dependent variable is shown as follows:

$$
Y=A_{0}+A_{1} X_{1}+\varepsilon
$$

where:

- $\quad Y=$ dependent variable (trade balance)

- $\quad X_{j}=$ independent variable (NEER) 
- $A_{0}=$ Constant

- $A_{1}=$ unknown parameter alongside the independent variable,

- $\varepsilon=$ an error that reflects all influences on the dependent variable (trade balance) that do not stem from an independent variable

Chart 3: Scatter plot NEER/trade balance

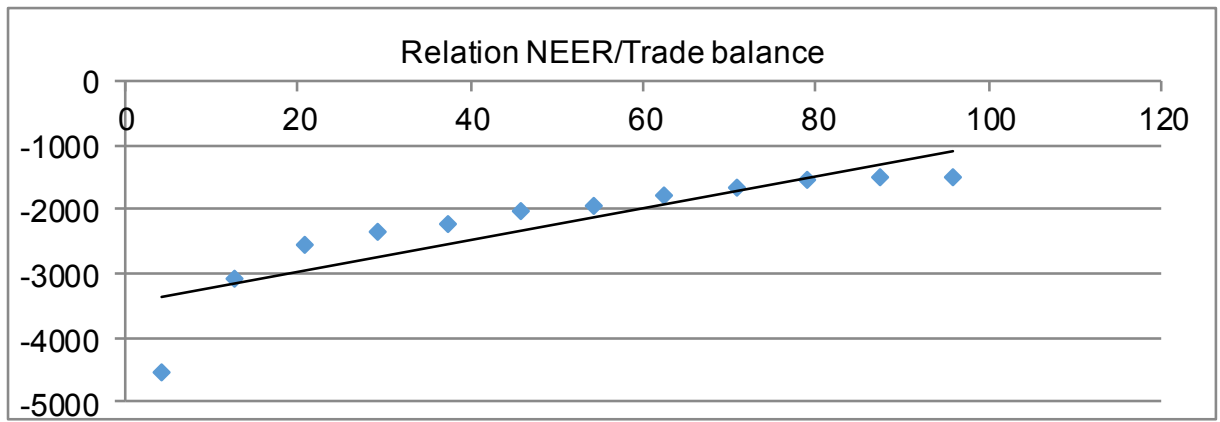

Source: Author's calculation

Econometric calculations have obtained the values of the correlation and determination coefficient, and thus the strength of a relationship and the influence of the dependent on the independent variable are determined. The value of the correlation coefficient of 0.557 shows the relationship between variations in the nominal effective exchange rate and the trade balance. Statistically, the value of $55.7 \%$ is close to the limit of $60 \%$, which is considered to be a high correlation between an independent and dependent variable.

The value of the determination coefficient of 0.310 indicates that $31 \%$ of the trade balance variation can be explained by the effect of the nominal effective exchange rate. The scatter plot shows the relationship between the variations of the independent and the dependent variable.

Calculations from the model showed the existence of a functional relationship between exchange rate variations and macroeconomic indicators that are the subject of the analysis. The stronger relation and determination of the exchange rate-GDP ratio in relation to the exchange rate-unemployment rate/trade balance ratio does not necessarily indicate a lower degree of relationship of the exchange rate influence on the two listed variables. Other economic as well as other variables considerably influence the variation of these variables, but the significant influence of the exchange rate cannot be excluded.

The analysis of the data from Table 2 on the rate of real GDP growth shows that the growth in the mentioned period was modest with an average growth rate of $2.25 \%$ 
over a period of 12 years. The value of the correlation coefficient of $62.8 \%$ between the real GDP growth and the real effective exchange rate provide an argument of impact of the currency board on narrow sustainable and inclusive economic growth. Although targeted macroeconomic indicators tend to increase their value, which is logical, given the catch-up effect, the analysis in the model proves the influence of the exchange rate on bounded sustainable economic growth in $\mathrm{BiH}$ in the long run.

\section{Results of analysis and possible alternatives of another exchange rate system}

The currency board system in Bosnia and Herzegovina fulfilled the goals it was created for. First of all, it prevented inflation, created macroeconomic stability and created the prerequisites for sustainable economic growth. However, its long-term influence has a destimulating effect on economic trends. First of all, by linking the national currency to the currency of a more developed country, the effects of monetary policy instruments are disabled. Spending foreign exchange reserves in times of crisis and the inability to stimulate the economy is in favor of the claim that a fixed exchange rate is a limiting factor of economic growth. The ability to conduct monetary policy is particularly important in the period of external shocks, when the mechanism of free movement of the exchange rate results in the depreciation of the national currency and thus stimulates exports and increases the import.

Devaluation of the national currency represents a powerful instrument in stimulating and improving the internal and international competitiveness of the national economy. The question is whether, in the present economic and political conditions, devaluation would be an effective stimulator of economic growth. Devaluation depends primarily on the quality of products and the ability of the national economy to provide sufficient export surpluses in line with the price elasticity of demand.

Taking into account the experience of the countries that have passed the currency board period, the next phase in the exchange rate policy should be abandoning the currency board system and moving to a managed-fluctuating exchange rate. Although macroeconomic models and theories explain the mechanism of freely fluctuating exchange rates, such exchange rates are not applied in real economic models. The exchange rate is a sensitive and important issue in the national economy for the countries to leave it to uncontrolled fluctuations and speculative movements in the foreign exchange market.

Therefore, the choice of the appropriate exchange rate should go in the direction of the fluctuating exchange rate but with the fluctuation range. Targeted goal zone of fluctuations should be defined in accordance with the strength of the national economy and its competitive position in relation to the main foreign trade partners. The current exchange rate system, which, as a result of strengthening of EUR, results in the appreciation of the domestic currency in relation to most foreign trade partners, adversely affects the manufacturing sector and the trade balance. Therefore, models of transition into a 
fluctuating exchange rate system with a determined fluctuation range must be defined. The assumptions for an effective change in the exchange rate system are the complete political and economic independence of the Central Bank of BiH and its full credibility and confidence in economic entities in the implementation of monetary policy.

\section{Discussion and conclusion}

The choice of the exchange rate system is one of the most important economic issues that significantly influences macroeconomic stability and economic growth. The experiences of countries, especially underdeveloped and transition countries, show that the choice of a fixed exchange rate system, in the period of transition to a market economy and macroeconomic instabilities, is the best solution. The fixed exchange rate in the given period enables macroeconomic stability and transaction security. Also, the experience of the countries is to switch from the fixed exchange rate system to the fluctuating exchange rate system in the period after the stabilization of macroeconomic parameters and economic growth.

Bosnia and Herzegovina represents a transitional country in which the currency board system is implemented, as a form of a rigid fixed exchange rate. The currency board system fulfilled the tasks for which it was created. Its action can be divided into two phases. In the first phase, the currency board system provided strong preconditions for macroeconomic stability and economic growth. The stability of prices and the exchange rate and the security of international payments are just some of the goals that have been achieved and which enabled economic growth. However, macroeconomic models and experiences of countries prove that the system has limited results on economic growth in the long run. The currency board system has been implemented for too long in $\mathrm{BiH}$ and thus affects the economic growth. By using the econometric calculations in the research, the hypothesis has been proven: The exchange rate of the convertible mark affects the growth of gross domestic product, employment and trade balance of Bosnia and Herzegovina.

The system of the currency board has enabled the movement of inflation rate in targeted frameworks, in line with the ECB's policy, as well as stability and security in relation to exchange rate movements and international transactions, thus creating the preconditions for the arrival of foreign direct investments and economic growth. But the long-term use of the currency board system had a destimulating effect on faster economic growth. Gross domestic product increased significantly, the unemployment rate decreased, as well as the trade balance deficit, but, taking into account the effect of catching up, the results are not impressive. The rate of real GDP growth is rather modest, and this was significantly contributed by the current exchange rate system. In the time of the global economic crisis and other external and internal imbalances, the impossibility to implement monetary policy instruments has significantly affected economic stability and growth. The appreciation of the domestic currency in relation to the main foreign trade 
partners in recent years, despite the low rates of economic growth, adversely affects the macroeconomic parameters.

Taking into account all the above stated facts, the conclusion is that the current exchange rate system is one of the factors that significantly hampers economic growth and should be replaced by another system. The system of managed-fluctuating exchange rate should be the next choice of the exchange rate. This system, with narrow limits of exchange rate fluctuations, represents a good precondition for faster economic growth and the possibility of implementing the autonomous monetary policy of the CBBH. Of course, the $\mathrm{CBBH}$ must have a high degree of political and economic independence in order to prevent possible abuse, first of all, in the field of money-creating policy. But there is no alternative to a change in the exchange rate if a faster economic growth is desired.

\section{References}

Baldwin, R., \& Wyplosz, C. (2010). Ekonomija evropskih integracija. Beograd: Data status.

Barro, R., \& Gordon, R. (1983). Rules, Discretion and Reputation in a Model of Monetary Policy. Journal of Monetary Policy, 12(1), 101-121. Doi:

https://doi.org/10.1016/0304-3932(83)90051-X

Blanchard, O. (2009). Macroeconomics. New Jersey: Prentice Hall.

Burda, C., \& Wyplosz, C. (2004). Makroekonomija, evropski udžbenik. Beograd: Centar za liberalno -demokratske studije.

Centralna banka Bosne i Hercegovine. (2018). Godišnji izvještaj 2017. Downloaded May 23 from https://www.cbbh.ba/Content/Archive/36

Centralna banka Bosne i Hercegovine. (2018). Metodologija za izračunavanje efektivnih kurseva. Downloaded May 23 from https://www.cbbh.ba/content/read/1109

De Grauwe, P., \& Schnabl, G. (2008). Exchange Rate Stability, Inflation and Growth in (South) Eastern and Central Europe. Review of Development Economics, 12(3), 530-549. Doi: https://doi.org/10.1111/j.1467-9361.2008.00470.x

Halpern, L., \& Wyplosz, C. (1997). Equilibrium Exchange Rates in Transition Economies. Palgrave Macmillan Journals, 44(4), 430-461. Doi:

https://doi.org/10.2307/3867461

Husain, A., Mody, A., \& Rogoff, K. (2005). Exchange Rate Regime Durability and Performance in Developing versus Advanced Economies. Journal of Monetary Economics, 52 (2005), 35-64. Doi: https://doi.org/10.1016/j.jmoneco.2004.07.001

Hefeker, C. (1997). Interest Groups and Monetary Integration: The political Economy of Exchange Regime Choice. Oxford: Westview Press. 
Kenen, P. (1969). The Theory of Optimum Currency Areas: An Eclectic View, in Mundell, R.; Swoboda, A. Monetary Problems of the International Economy. University of Chicago Press: 41-60.

Kovačević, P. (2016). Međunarodne finansije. Beograd: Centar za istraživačku delatnost, Ekonomski fakultet.

Kozarić, K. (2007). Modeli monetarne politike sa osvrtom na valutni odbor Bosne i Hercegovine. Sarajevo: Centralna banka Bosne i Hercegovine, 1(7), 2-82.

Krugman, P. (1991). Target Zones and Exchange Rate Dynamics. Quarterly Journal of Economics, 106(3), 669-682. Doi: https://doi.org/10.2307/2937922

Krugman P., \& Miller, M. (1992). Exchange Rate Targets and Currency Bands. New York: Cambridge University Press.

Krugman, P., \& Obstfeld, M. (2009). Međunarodna ekonomija: Teorija i politika. Beograd: Data status.

Mankiw, G., \& Taylor, M. (2006). Economics. Boston: Cengage learning.

McKinnon, R. (1963). Optimum Currency Areas. The American Economic Review, 53 (4), 717-725. Retrieved May, 2019, from https://www.jstor.org/stable/1811021?seq=1

Mundell, R. (1961). A Theory of Optimal Currency Areas. The American Economic Review, 51(4), 657-665. Retrieved May 27, 2019, from https://www.jstor.org/stable/1812792?seq=1

Rusydi, M., \& Islam, S. (2007). Quantitative Exchange Rate Economics in Developing Countries. A New Pragmatic Decision-Making Approach. New York: Palgrave Macmillan.

Sachs, J. (1996). Economic Transition and Exchange-Rate Regime. The American Economic Review, 86(2), 147-152. Retrieved May 17, 2019, from https://www.jstor.org/stable/2118113?seq=1

Svensson, L. (1992). An interpretation of Recent Research on Exchange Rate Target Zones. Journal of Economic Perspectives, 6(4), 119-144. Doi:

https://doi.org/10.1257/jep.6.4.119

Hagen, J. V., \& Zhou, J. (2005). The Choice of Exchange Rate Regime: an Empirical Analysis for Transition Economies. Economics of Transition, 13(4), 679-703. Doi: https://doi.org/10.1111/j.0967-0750.2005.00237.x 